\title{
Erratum to: Acaricidal and antimicrobial toxicities of Cyanachum paniculatum root oils and these components against Haemaphysalis longicornis and human intestinal bacteria
}

\author{
Myung-Ji Lee ${ }^{1} \cdot$ Hui-Ju Kim ${ }^{1} \cdot$ Ah-Hyeon Jeong ${ }^{1} \cdot$ Hoi-Seon Lee ${ }^{1}$
}

Published online: 31 March 2019

(C) The Korean Society for Applied Biological Chemistry 2019

Erratum to: J Appl Biol Chem (2018) 61, 423-428 DOI 10.3839/jabc.2018.060

\section{p. 427}

We will modify the Acknowledgments.
The online version of the original article can be found under. doi: $10.3839 /$ jabc. 2018.060

Acknowledgments 본 연구과제는 방역연계 범부처 감염병 연구개발 사업 (HG18C0055)의 지원으로 수행되었습니다.

Hoi-Seon Lee $(\bowtie)$

E-mail:hoiseon@jbnu.ac.kr

${ }^{1}$ Department of Bioenvironmental Chemistry, Chonbuk National University, Jeonju 54896, Republic of Korea

This is an Open Access article distributed under the terms of the Creative Commons Attribution Non-Commercial License (http://creativecommons. org/licenses/by-nc/3.0/) which permits unrestricted non-commercial use, distribution, and reproduction in any medium, provided the original work is properly cited. 